\title{
A HARMONY AMONG OF RELIGIOUS COMMUNITY IS REQUIRED AMIDST THE COVID-19 PANDEMIC
}

\author{
E. Handayani Tyas ${ }^{1}$, Lamhot Naibaho ${ }^{1}$ 厌 \\ ${ }^{1}$ Jakarta. Jl. Mayjen Sutoyo No. 2 Cawang, Jakarta Timur, Universitas Kristen Indonesia
}

DOI: https://doi.org/10.29121/granthaalayah.v8.i9.2020.1583

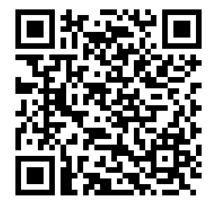

Article Type: Research Article

Article Citation: E. Handayani Tyas, and Lamhot Naibaho. (2020). A HARMONY AMONG OF RELIGIOUS COMMUNITY IS REQUIRED AMIDST THE COVID-19 PANDEMIC. International Journal of Research GRANTHAALAYAH, 8(9), 422-428. https://doi.org/10.29121/granthaa layah.v8.i9.2020.1583

Received Date: 15 September 2020

Accepted Date: 30 September 2020

Keywords:

Harmony

Religious Community

COVID-19 Pandemic

\section{ABSTRACT}

This article is about a harmony among of religious community which is required amidst the COVID-19 Pandemic. It is written in to inform the religious communities especially in Indonesia to be able to live in harmonious way amidst the COVID-19 Pandemic. It is a qualitative research with the "Library Research" design, where researchers as "key instruments" by reading the theories that are directly related to the topic of "A Harmony among of Religious Community is required amidst the COVID-19 Pandemic" sourced from Pubmed, Google Scholar, Google with keywords building a culture of tolerance since early childhood. The result shows that all of Indonesian people and other nations in the world face the Covid-19 pandemic which requires togetherness and mutual assistance, the urgency of solidarity and harmony between religious believers is even more significant, because if you are careless, the Covid-19 pandemic can trigger rifts and even conflicts among the nation's children. Educational leaders, religious leaders, community leaders, all moved to make their citizens comply with health protocols.

\section{INTRODUCTION}

The Unitary State of the Republic of Indonesia has the motto Bhinneka Tunggal Ika (Unity in Diversity). The motto is chosen and defined as a unifying symbol for the plurality of the nation. It can be said that it is not just a slogan or slogan but a philosophy that is expected to be inspired by every Indonesian in building the spirit of nationalism as a nation. Each individual must be able to live side by side with others and uphold the ethical values of life, and always strive to create a real, just, and peaceful community [1], [2], [3]. Therefore, do not let differences become an arena for division/conflict between one another, and the seeds of intolerance do not need a place to live on the whole earth.

Each individual is expected to be able to appreciate and respect the existence and diversity so that harmony and beauty will appear, and always learn to motivate themselves to live in the principle of balance. Able to live side by side with others and uphold the ethical values of life [4], [5]. Always strive to create a real and peace-loving community, so that it is hoped that it can reduce conflict/violence and harmony between religious believers in Indonesia during the Covid-19 pandemic as is currently being experienced by all nations in the world [6], [7].

Therefore, do not let differences become an arena for division/conflict between one another. The existence of various ethnic groups in Indonesia shows the enormous diversity of cultures, customs and customs that are different from Sabang to Merauke and from Miangas to Rote Island. Bung Karno called it a "strand of zamrut on the equator"

(C) 2020 The Author(s). This is an open access article distributed under the terms of the Creative Commons Attribution License, which permits unrestricted use, distribution, and reproduction in any medium, provided the original author and source are credited. 
which was so beautiful, rich and prosperous that it had to be continuously cared for in order to build a strong nationalism in Indonesian soil.

In general, interreligious relations in Indonesia are running well in almost all parts of Indonesia, although it cannot be denied that there are still some problems. As a pluralistic nation like Indonesia, it requires high tolerance from every citizen in building a life together [8], [9]. The creation of harmony between religious believers must be nurtured and cared for endlessly [10], [11]. The spirit of cooperation and independence is an antibody against various crises in this country, both those in the health sector and the economic crisis. Like 'conjoined twins', one is named Corona aka Covid-19, and the other is called social disintegration. Two vicious "beings" that threaten human existence live in this realm.

Both were able to paralyze the country's economy, which led to an increase in unemployment and poverty and a terrible dash of hope. This problematic situation will be very vulnerable if it is "ridden" by conflicts between religious believers. The work of competing against one another and the spread of hoaxes are potent tools to destroy the unity and integrity of the nation. Be vigilant, that is the keyword that we must protect together so that this nation is not easily divided and able to get out of the crisis that is twisting, who knows how long it will end.

In recent years, particularly after the 1998 Reformasi, there have been sources of tension in inter-religious community relations, which have often turned violent. This communal violence involves communities of different religions on a large scale, such as some cases that occurred around 1998. However, currently, there are two main types of cases that often arise, namely the issue of places of worship and discourses of misdirection towards groups within a religion or groups. New religion such tensions have, in many cases, led to the use of violence by certain groups of society [12], [13].

During the first period of Mr Joko Widodo's administration (November 2014 to October 2019) the Setara Institute noted that there had been 846 incidents of violations of freedom of religion and belief. Intolerant groups commit freedom of religion and belief violations with radical ideologies, both by non-state actors (mass organizations/religious mass organizations, citizens, to religious leaders and religious forums) and state actors in the form of religious nuanced regional regulations, village governments, etc [14], [15].

The types of violations include prohibiting worship or establishing/renovating places of worship, even destroying or burning places of worship, persecution, discrimination, and the prohibition of various religious activities. KBB violations are puritan propaganda which undermines diversity very visibly because it indicates a strengthening expression of conservatism and a narrative of intolerance. An example that the writer can put forward here is the recent incident in Solo (August 8, 2020) in the form of the dissolution of the midodareni event (the night before a pair of brides were matched). It is clear that this incident is very concerning and is strong evidence of violations by non-state actors (mass organizations), which the state actor (police) then responds to with neglect (big problem syndrome) so that the anarchic action continues. This case shows that in this beloved country Indonesia is faced with two "pandemic viruses" whose effects can be deadly, the first is the Covid-19 virus and the second is the radical ideological virus of intolerant groups which is very worrying. For the first, it has been proven to have caused thousands of people to die because of the ferocity of the virus, and it is still very possible that the number will continue to grow because there is a new type of coronavirus called SARS-CoV-2. In contrast, the second, apart from casualties, is also the impact of damage losses experienced in the midst of the economic difficulties that are plaguing this country.

\section{METHOD}

The method used in this paper is qualitative research with the "Library Research" approach, where researchers as "key instruments" [16] read theories that are directly related to the topic of "A Harmony among of Religious Community is Required amidst the COVID-19 Pandemic" sourced from books, journals and proceedings (Pubmed, Google Scholar, Google with keywords building a culture of tolerance since early childhood) as well as other documents and turn them into research data which were analyzed descriptively.

\section{DISCUSSION}

Indonesia is a country that loves peace, as implied in the motto Unity in Diversity. In a plural society like in Indonesia, harmony between religious believers is necessary. Indonesia consists of more than 17,500 large and small 


\section{E. Handayani Tyas, and Lamhot Naibaho}

islands, each of which is inhabited by various ethnic groups (there are 1,340 tribes), and there are six religions recognized by the government (Islam, Catholicism, Christianity, Buddhism, Hinduism and Confucianism). Race and customs, stretching from Sabang to Merauke and from Miangas to Rote Island, would be very vulnerable if they claim each other's truth. Even if they are not of the same religion, they are both human beings, God's creatures who are taught to respect, love and help each other.

Humans are friends to fellow humans (homo socius), but humans are also wolves to fellow humans (homo homini lupus) [17], [18]. The sentence in Latin written by the Roman poet, Titus Maccius Plautus (205 - 184 BC) and equipped with the Roman philosopher, Lucius Annaeus Seneca (4 BC - 65 AD) describes human nature. Humans can glorify others, but also can become "enemies" to others. The two sentences were put together by the English philosopher, Thomas Hobbes (1588 - 1679), in his deceive. The picture of humans with these two opposing traits is evident when the world is facing the current Covid-19 pandemic.

Quoting data from Worldometers.info, Sunday (September 6 2020), it was recorded that more than 27.11 million citizens of the world tested positive for the new coronavirus, so that countries in the world are competing with each other to find a vaccine or antidote, so come together, humankind to build solidarity among each other [19], [20]. That is the message conveyed by Pope Francis, the leader of the worldwide Catholic Church. The coronavirus should make humans everywhere feel the same fate. Therefore, it is only natural for humans to feel obliged and help each other, helping each other for the common good, and building solidarity against the pandemic. According to the Big Indonesian Dictionary, the word solidarity is defined as nature (feeling) of solidarity, the nature of one feeling (the same fate), as the feeling of being loyal to friends.

Under the motto of diversity, the Indonesian nation has great potential to have a rich perspective in seeing various problems. The awareness that the Indonesian nation is plural was realized long before independence on August 17, 1945, with the Youth Pledge on October 28, 1928 (one blood oath, Indonesian homeland; one nation, the Indonesian nation; upholding the language of unity, the Indonesian language) as a significant milestone. Therefore, please do not allow growing primordialism and feudalism, which could potentially be misused in order to separate oneself from the plurality that exists in Indonesia [21].

One more challenge for Indonesia's diversity is the tendency of majoritarianism in some people. Majoritarianism is often interpreted as a desire so that the fate of the nation is only determined and controlled by the majority group, while the minority plays a passive, minimal, or silent role. In response to this, it is necessary to recall the words/words that Bung Karno had conveyed about the purpose of establishing this country: "Are we going to establish an independent Indonesia for something, for a group? ... Of course not !. ...... It is not such a country that we aim for. We want to establish a nation for all "(Soekarno. 1947).

The challenge for this nation in the future is how to change the still segmented and fragmented diversity into a beautiful and enchanting mosaic. Recognition of diversity is not enough to stop in acknowledgement and knowledge of the reality of the pluralistic Indonesian nation, but we need a way to celebrate and fill it. Every Indonesian citizen needs to feel optimistic that inter-religious harmony can be realized because one of the fundamental values of Indonesian society is cooperation, a high spirit of sharing and cooperation, and a willingness to sacrifice for others. The philosophy of "torang samua basudara", one nation amidst diversity needs to be echoed continuously, especially during the Covid-19 pandemic as we feel together today.

Awareness of the pluralistic condition of this nation must be maintained, how to manage diversity, how to recognize differences and at the same time, strive for equality [22], [23]. In a pluralistic democratic society, the main question is how to manage this diversity? The diversity that exists in society, including language, ethnicity, religion is a fact of life today that cannot be denied. The tension between "unity" and "diversity" is a significant issue in understanding Bhinneka Tunggal Ika. The main hope is not to solve this complex problem, but at least it can be stimulation to talk about the old problem in a new way.

Bhikhu Parekh said the more diverse a society is and the more profound its diversity, the greater cohesion or unity is needed to bind that society. Parekh sees that in the public sphere, diversity must continue to emerge; it cannot just be tolerated. He argues: "Without having to agree on all the values and practices of (different groups), a multicultural society must find a way to reshape the public sphere along multicultural (diversity) lines. The public and private areas that are formed in a multicultural manner then support each other and allow the spirit of cultural diversity to enter smoothly into the various areas of life and live the multicultural ethos of society as a whole" [24], [25] In this way, according to Parekh, diversity does not become divisive, while unity does not become abstract. It is a challenge, namely, how to have unity without uniformity. 
Even though Article 29 of the 1945 Constitution, guarantees freedom of religion, the law has regulated other aspects which may directly or indirectly involve diversity. Apart from guaranteeing freedom of religion, another role of the State is in accommodating diversity. Prof. Dr Moh. Mahfud M.D. emphasized that Article 29 of the 1945 Constitution outlines the duty of the State to protect religious freedom. Furthermore, Mahfud said: "In the context of the Indonesian State which recognizes the critical position of religion, protection of religious freedom must be combined with protection of the purity of religious teachings. It means that deviant religious freedom cannot be justified. The responsibility of the State towards religion is not only limited to protecting religious freedom to adherents of religion but also providing services to religious believers and protecting the purity of religious teachings from abuses or deviations".

The Wahid Institute has a Monthly Report on Religious Freedom Program, which is an effort to develop an index of religious freedom and diversity of life in general that can be used to monitor and assess the extent to which constitutional guarantees of the fundamental rights of citizens are implemented by the government. It seems that awareness of the importance of harmony between religious believers and between societies of different cultures does not appear to be a common concern that all levels of society should live and practice. It is a big problem in Indonesia, in addition to other problems that are no less big.

Understanding that harmony is (always) problematic [26], [27] why does it happen, even over and over? We live in a country that has a Pancasila philosophy. If this nation understands and can internalize the Pancasila into itself, then there is no need to question the things that can trigger and spur disputes, chaos, radicalism and intolerance in Indonesian soil that is eminent ripah jinawi (peaceful and prosperous and very fertile land). In contrast, the prosperous agawe santoso means that prosperity will produce inner and outer peace and make prosperous. Isn't it precisely the diversity of ethnicities - religions - races - customs that will make Indonesia rich. Indonesia that is plural, Indonesia that is plural, Indonesia which is full of tolerance, harmony, friendly, safe and prosperous?

Dachlan said: "The existence of harmony between religious groups is an absolute prerequisite for the realization of political and economic stabilization which was the program of the Ampera Cabinet (at that time). Therefore, we sincerely hope that there will be cooperation between the government and the religious community, so that the demands of the people's conscience and our common aspirations to create a just and prosperous society protected by God Almighty can truly take shape".

The role of the family and the role of society is indispensable in a harmonious cooperation bond as an agent for the transformation of the Indonesian nation. In the realm of the family, it is needed as a place for individual/individual moral sowing, through the cultivation of religious morals and role models from an early age [28], [29]. Ethnic, religious, racial and customary communities, as well as the community environment, are needed to strengthen the moral foundation (starting from the family) through learning religious morals, customs, local wisdom and code of conduct. Therefore, do not let differences become an arena for division/conflict between one another. Each individual must be able to live side by side with others and uphold the ethical values of life.

The creator created humans to realize His will, which is to form a life that is peaceful, peaceful, and happy and prosperous. Every religious adherent (religious community) should be aware of the plurality in this country. Indonesia is not a religious state, but a religious state (Article 29 of the 1945 Constitution states that every individual gathered in one community of his respective religion demands recognition and fair treatment). Plurality is understood as more than just tolerance, but an active attempt to understand differences. The plurality does not want to unite all people in the same understanding but instead accepts and maintains differences. In a broad sense, plurality is defined as the acceptance and appreciation of diversity and efforts to cooperate with other people or groups for the common good.

The exemplary elements of parents, educators, religious leaders and community leaders have spearheaded the creation of harmony and peace in Indonesia. Deep in the deepest heart of every human being, indeed you still long for peace, tranquillity and harmony. Taking part in creating religious harmony is an act of worship that is acceptable to Him. The basis is, namely: "So because of the grace of Allah, you are gentle towards them, if you act harshly and harshly hearted, of course, they distance themselves from around you, then forgive them and ask forgiveness for them, and consult with them in some matters. While in another section: "Blessed are the peacemakers, for they will be called the children of God".

Religious education in schools should be reviewed, and curricula that tend to emphasize religious ritual only need to be enriched by instilling an awareness of national life. Religious education in some schools has been susceptible to being infiltrated by thoughts that are anti-concept of nationalism that respect the plurality of society. 


\section{E. Handayani Tyas, and Lamhot Naibaho}

This condition is very concerning and needs to be addressed immediately by improving the curriculum that prioritizes ethics, national unity, and the achievement of good universal values. Religious education should focus on substantive matters, such as character, religion as a national reinforcement and ritual implementation with universal goals [30], [31], [32]. The religious curriculum should encourage understanding of nationality and respect for differences. It is also necessary to instil awareness; religious expression is the right of every citizen so that it does not need to be stigmatized. Religious education must be able to build a culture of critical argumentation.

Education should encourage a plurality of thinking and respect pluralism so that students are not only intelligent in reasoning but also intelligent in thinking; education should not only produce smart people but less respect for diversity. The reason often becomes very sharp, but also shrinks diversity, education should integrate reason and reason, but in fact, education now emphasizes content too much. The tendency to think singularly does not develop creativity, linear thinking causes anti-reality, so it is not surprising that many college graduates whose way of thinking is still low, Lower medium Order Thinking Skills (LOTS), which is just memorizing, understanding, and applying. Whereas now what Higher Order Thinking Skills (HOTS) is needed, namely the ability to analyze, evaluate, and create (creation). This condition is also reflected in the test results of Indonesia's International Student Assessment Program (PISA), which so far are still below the average world score; Do not let Indonesian children go to school, but not yet learning!

Critical and dynamic thinking will help a person to be able to appreciate the strengths of others and their shortcomings and learn to motivate oneself to live in a balanced principle. Through education, there is a process of sowing and disseminating ideas, values, a spirit of solidarity, paradigm, knowledge, attitudes, and characters, all of which will lead to a consensus, that we are one and we are brothers and sisters, although in many ways we are remains different. The role of education (from elementary schools to tertiary institutions) plays a significant role in shaping the younger generation to become citizens who are not fanatical, erroneous. The young generation is the nation's asset, and people often call it the backbone of the country, so if Indonesia wants to advance, educate the children, adolescents, youth, because learning has to last a lifetime (lifelong education or lifelong learning), there is no time limit for one to study. By learning we become smart, and usually, smart people can control themselves, the wiser (wise).

However, the problem now is that the Covid-19 Pandemic is still unknown when it will end so that the Indonesian people can interact actively and effectively, but still pay attention to and apply health protocols with full discipline. With a spirit of cooperation and a high work ethic, we will have antibodies to fight various national crises, including the new corona attack. In facing the current crisis, let us remain harmonious and not be easily pitted against each other, especially if everything is wrapped in religion, this nation could ruin! To respond to the Covid-19 outbreak, religious communities and their leaders are more open theologically and spiritually so that they can contribute to preventing it and not, on the contrary, worsening the situation. Consequently, religious communities need to reinterpret their theological and spiritual understanding in dealing with the existing situation.

Almost all religions teach that worship together is an obligation. In everyday situations, online worship has generally not been accepted by religious communities. However, it is grateful that in an emergency situation like now many religions have advocated using online worship services and social distancing or isolating oneself in this situation would be wiser than the other way around. This global catastrophe teaches us how crucial global solidarity is. The power of unlimited solidarity is the ultimate weapon to defeat the onslaught of a vicious virus that produces social pathologies. Resistance can start from the smallest social unit, namely the family, and spread to the level of neighbourhood associations, community groups, sub-districts, sub-districts, to the national level.

What learners need in this Covid-19 emergency is not an increasing pile of task demands. Nor is it solidarity in the sense of being sad. Like all of us, they need hope, and it is this hope that must not be lost. The hope that education in any situation can creatively stretch the human within each person to keep reaching others in real action. What is no less important is that every educator, both at the formal, non-formal, and informal levels of education is required to have an art and intelligence of its own in developing Indonesia through education. Every educator must be able to create a relaxed and peaceful learning climate because education is the spearhead of creating much-needed harmony between religious believers. Alternatively, in other words, inter-religious harmony in Indonesia needs to be promoted through education.

President Joko Widodo stated that diversity in Indonesia is a gift and a necessity. More than that, diversity becomes the capital for the progress of the nation. For that, public openness and tolerance need to be built and continuously strengthened. He made this speech when he opened the Meeting Point Forum for Multicultural Cooperation for Unity and Justice in Jakarta, Wednesday, September 18 2019. Previously, President Susilo Bambang 
A Harmony Among of Religious Community is Required Amidst the Covid-19 Pandemic

Yudhoyono also stated that the diversity of the Indonesian nation did not place certain groups above other groups. Likewise, President Abdurrahman Wahid emphasized that: We have various religions and languages. All are our essence as one and inseparable people.

\section{CONCLUSION}

The spirit of Bhinneka Tunggal Ika and cooperation is an attitude and tradition that has been taught from generation to generation in Indonesia. This spirit has bound the nation's solidarity to this day. Feelings of compatriots without seeing differences and self-interest or groups to work together to make big things for the future together cannot happen by itself. The spirit of solidarity among the nation's children needs to be continuously cared for and built. When the Indonesian people and other nations in the world face the Covid-19 pandemic which requires togetherness and mutual assistance, the urgency of solidarity and harmony between religious believers is even more significant, because if you are careless, the Covid-19 pandemic can trigger rifts and even conflicts among the nation's children. Educational leaders, religious leaders, community leaders, all moved to make their citizens comply with health protocols, although this is certainly not easy.

\section{SOURCES OF FUNDING}

This research received no specific grant from any funding agency in the public, commercial, or not-for-profit sectors.

\section{CONFLICT OF INTEREST}

The author have declared that no competing interests exist.

\section{ACKNOWLEDGMENT}

None.

\section{REFERENCES}

[1] Peck, M. S. (2010). The different drum: Community making and peace. Simon and Schuster.

[2] Held, V. (2006). The ethics of care: Personal, political, and global. Oxford University Press on Demand.

[3] Philpott, D. (2015). Just and unjust peace: An ethic of political reconciliation. Oxford University Press.

[4] Olsthoorn, P. (2009). A Critique of Integrity: Has a Commander a Moral Obligation to Uphold his Own Principles?. Journal of Military Ethics, 8(2), 90-104.

[5] Westius, A., Kallenberg, K., \& Norberg, A. (2010). Views of life and sense of identity in people with Alzheimer's disease. Ageing \& Society, 30(7), 1257-1278.

[6] Nadeak, B., Naibaho, L., \& Silalahi, M. (2020). COVID-19 and Students' Anxiety Management. International Journal of Innovation, Creativity and Change, 13(7), 1574-1587.

[7] Nadeak, B., Juwita, C. P., Sormin, E., \& Naibaho, L. (2020). Correlation of Students' Critical Thinking Ability and Use of Social Media on Learning Outcomes during the Covid-19 Pandemic. Jurnal Konseling dan Pendidikan, 8(2), 98-104.

[8] Brown, W. (2009). Regulating aversion: Tolerance in the age of identity and empire. Princeton University Press.

[9] Ogden, G. (2019). Discipleship essentials: A guide to building your life in Christ. InterVarsity Press.

[10] Nadeak, B., Deliviana, E., Sormin, E., Naibaho, L., \& Juwita, C. P. (2019). Pembinaan Ketahanan Pernikahan dan Keharmonisan Keluarga Dengan Tema "The Family Relationship and Intimacy. Jurnal ComunitÃ Servizio: Jurnal Terkait Kegiatan Pengabdian kepada Masyarakat, terkhusus bidang Teknologi, Kewirausahaan dan Sosial Kemasyarakatan, 1(2), 179-185.

[11] Naibaho, L. (2014). Peran Pendidikan dan Kebudayaan dalam Pembangunan Karakter dan Peradaban Bangsa Indonesia yang Majemuk. Jurnal the Ary Suta Center Series on Strategic Management, 27(0), 69. 
[12] Stewart, F. (Ed.). (2016). Horizontal inequalities and conflict: Understanding group violence in multiethnic societies. Springer.

[13] Richardson, J. (2001). Minority religions and the context of violence: A conflict/interactionist perspective. Terrorism and Political Violence, 13(1), 103-133.

[14] Clarke, B. (2008). Ideological Extremism and the Abuse of Religion:'Punishment of Apostasy'as a Rationale for Religious Violence by State and Non-State Actors.

[15] Clarke, B. (2009). Law, Religion, and Violence: A Human Rights-Based Response to Punishment (by State and Non-State Actors) of Apostasy. Adel. L. Rev., 30, 111.

[16] Nadeak, B., \& Naibaho, L. (2019). Managing Lecturers' Competence Development at Universitas Kristen Indonesia.

[17] De Waal, F. B. (2005). Homo homini lupus? Morality, the social instincts, and our fellow primates. In Neurobiology of human values (pp. 17-35). Springer, Berlin, Heidelberg.

[18] Suneetha, P. (2010). 'Homo homini lupus': A Note on Hilary Mantel's Wolf Hall. IUP Journal of English Studies.

[19] Benvenisti, E. (2013). Sovereigns as trustees of humanity: on the accountability of states to foreign stakeholders. American Journal of International Law, 107(2), 295-333.

[20] O'Brien, K., Hayward, B., \& Berkes, F. (2009). Rethinking social contracts: building resilience in a changing climate. Ecology and Society, 14(2).

[21] Barrington, L. W. (Ed.). (2009). After Independence: Making and Protecting the Nation in Postcolonial and Postcommunist States. University of Michigan Press.

[22] Kraatz, M. S., \& Block, E. S. (2008). Organizational implications of institutional pluralism. The Sage handbook of organizational institutionalism, 840, 243-275.

[23] Winter, E. (2011). Us, them and others: pluralism and national identities in diverse societies. University of Toronto Press.

[24] Ely, R. J., \& Thomas, D. A. (2001). Cultural diversity at work: The effects of diversity perspectives on work group processes and outcomes. Administrative science quarterly, 46(2), 229-273.

[25] Banks, J. A. (2015). Cultural diversity and education: Foundations, curriculum, and teaching. Routledge.

[26] Holmes, P. (2008). Foregrounding harmony: Chinese international student's voices in communication with their New Zealand peers.

[27] Wu, Y. C. D. (2016). When Quality Reaches Its Limit: A New Interpretative Approach to Understand Post-tonal Harmony. Musicology Australia, 38(1), 79-107.

[28] Tyas, E. H., \& Sunarto, L. N. (2020). Building Superior Human Resources through Character Education.

[29] Gagné, K. (2020). The materiality of ethics: Perspectives on water and reciprocity in a Himalayan Anthropocene. Wiley Interdisciplinary Reviews: Water, e1444.

[30] Tyas, E. H., \& Naibaho, L. (2020). Building a Culture of Tolerance since Early Childhood. International Journal of Research-GRANTHAALAYAH, 8(8), 244-249.

[31] Kittelmann Flensner, K. (2015). Religious education in contemporary pluralistic Sweden.

[32] Fountain, P. (2013). The myth of religious NGOs: Development studies and the return of religion. In International Development Policy: Religion and Development (pp. 9-30). Palgrave Macmillan, London. 